\title{
Critical perspectives on migration in discourse and communication: An introduction
}

Dimitris Serafis*, University of Malta, Institute of Linguistics and Language Technology, Malta Jolanta Drzewiecka, USI - Università della Svizzera italiana, Institute for Public Communication, Switzerland

Sara Greco, USI - Università della Svizzera italiana, Institute of Argumentation, Linguistics and Semiotics, Switzerland

*Corresponding author: serafisdimitris@gmail.com

While these lines were written, Taliban were conquering Afghanistan, establishing a regime of terror in the country, while concurrently provoking a wide conflict in the Western public sphere about responsibilities and consequences of this situation. More specifically, Europe witnesses a racist and xenophobic wave of discourses against a new possible escape of refugees toward Europe; presently such discourses abound in politics and the media. It is more than a truism nowadays that, in crisis-stricken Europe, there is an increasing politicization of migration, which takes place against the background and mutual overlapping of diverse crises. More specifically, migration has become a focal and quite polarizing issue in the European public sphere especially since the numbers of refugees, escaping from conflict territories of the Middle East (e.g., Syria), crossing the Mediterranean, dramatically increased starting in 2014 (Bevelander \& Wodak, 2019a). The so-called "refugee crisis," as this movement was portrayed by mainstream media and powerful political figures in Europe (Krzyżanowski, Triandafyllidou, \& Wodak, 2018), contributed to social and economic tensions (such as the Eurozone "debt crisis") that took place in the European Union and played into Brexit that followed.

Against this backdrop, refugee and migrant populations were met with solidarity by groups of European citizens and NGOs while, simultaneously, they were scapegoated by extreme right-wing voices and attacked both physically and symbolically, revealing the intensity of racist hatred in the European Union. The images of citizens, for example, in Lesbos island, Greece, rescuing and hosting refugees who were fleeing from the Turkish coast, and the pro-refugee manifestations yielded to a wave of exclusionary discourses such as the right-wing populist UKIP's anti-EU campaign, which was founded on an anti-migration sentiment and favored by mainstream British media (Cap, 2018). Moreover, fences were raised among EU member-states (Rheindorf \& Wodak, 2018), the debate on the Schengen area was thrown in turmoil (Boukala \& Dimitrakopoulou, 2018), and the essence of the project of the European integration was put to the test (Bevelander \& Wodak, $2019 \mathrm{~b}$ ) due to the rise of what has been called politics of fear (Wodak, 2015).

As a consequence, the "refugee crisis" and the related developments in the public sphere attracted huge multidisciplinary research interests in the fields of communication and discourse studies (Balabanova \& Trandafoiu, 2020; Krzyżanowski, Triandafyllidou, \& Wodak, 2018; Musolff, 2017; Viola \& Musolff, 2019; among others). To name but a few of the recent studies on the topic, scholars focused on analyzing dehumanizing metaphors (e.g., Musolff, 2015) such as "flows / tides of migrants," as a means that favor the exclusion of the migrant populations from the host societies. Moreover, in some cases, scholars have shown how discursive constructions of migrant and refugees contributes to the construction of explicit and implicit argumentation and consequently justifying racist exclusionary views (e.g., Serafis, 
Greco, Pollaroli, \& Jermini-Martinez Soria, 2020a, 2020b; Serafis, Raimondo, Assimakopoulos, Greco, \& Rocci, 2021).

This Thematic Section aims to deepen the relevant scholarly discussion about the issues highlighted before by bringing to the fore critical cutting-edge research from discourse and communication studies on migration in different European contexts where the so-called "refugee crisis" played out. In particular, the papers included in this Thematic Section represent different scholarly perspectives from a multidisciplinary mosaic of approaches, with a particular focus on Spain, Italy, Greece, and Germany. In many ways, the papers expand previous research by focusing, for example, on migration in relation to the ongoing COVID-19 public health crisis, or on the (re-)emergence and the ultimate naturalization of extreme right-wing populist forces and voices in different EU settings, as well as the time frame to understand how migration is represented in discourses after the 2015 peak period.

Focusing on Spain, in her paper, "Refugees, coronavirus and the politics of representation in the Spanish press," Alicia Ferrández-Ferrer cross-examines the migration issue in relation to the COVID-19 pandemic outbreak. The author focuses on the Spanish mainstream press. More specifically, she analyzes news articles published by the Spanish newspapers El País and El Mundo, showing that representations of migrants have changed owing to the COVID-19 pandemic. In particular, the author shows that there are shifts toward a representation of migrants and refugees as victims or as a threat, but also a portrayal of migrants as necessary and as active agents in the context of a global emergency.

Examining political discourse in the Italian context, in his paper "Emergenza sanitaria, emergenza immigrazione. Il discorso anti-immigrazione di Matteo Salvini," Dario Lucchesi analyzes rightwing populist discourse of Matteo Salvini on social media, with a particular focus on migration (March 2020-March 2021). The author synthesizes quantitative analysis and critical discourse analysis to study Salvini's posts and user comments.
He identifies the linguistic strategies that contribute to the construction of a sense of emergency and reinforce the process of "securitization" of national borders and the re-legitimation of national identities. The author shows that Salvini systematically organized the migratory narrative on negative campaigning, blaming political opponents, and recontextualized the moralization of borders.

Turning to the Greek context, in the paper "Far-right discourse as legitimacy? Analysing political rhetoric on the "migration issue' in Greece," Salomi Boukala follows a discourse-historical approach (DHA) to critical discourse studies (CDS) to show the normalization of far-right political rhetoric on the migration issue. She does so by analyzing statements from mainstream political representatives, namely the current Greek prime minister, Kyriakos Mitsotakis, and political figures from the ruling political party New Democracy. In particular, the author uses an argumentative-based DHA approach, considering the argumentative schemes of Aristotelian topoi and the study of fallacies to investigate how the leadership of the Greek government justified its political agenda on security, law, and order, thus underpinning a far-right rhetoric.

Within the same national context, in their paper "From the illegal migrant-criminal to the illegal migrant-invader: Critical analysis of the semantic change of the

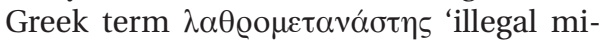
grant'," Nikos Stamatinis, Argiris Archakis and Villy Tsakona provide evidence from the analysis of the Hellenic Parliament Pro-

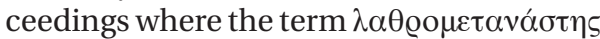
"illegal migrant" is used. Following a critical discourse-analytical perspective and employing the principle of the interplay between macro-level dominant discourses vs. micro-level discursive choices and strategies, the authors trace the semantic trajectory of such a term, showing how this was re-contextualized in relation to the hegemonic national-racist discourse of the 1990s, in which migrants were perceived as criminals. Moreover, they examine how the re-emergence of the older racist use of the term in question as a reaction against 
the guidelines of political correctness is anew connected with national-xenophobic discourse, that tends to frame migrants as invaders and a national threat.

Finally, in their paper "The 'refugee crisis' as an opportunity structure for right-wing populist social movements: The case of PEGIDA," Marco Bitschnau, Dennis Lichtenstein and Birte Fähnrich focus on the strategic communication of the rightwing PEGIDA movement in Germany. In particular, they unveil the frames and master frames of the PEGIDA movement and the role of the 2015 "refugee crisis" in shaping them. They employ a qualitative content analysis of speeches held at PEGIDA rallies between 2014 and 2016. Their paper shows that PEGIDA employed the alleged "Islamization of Europe" as the only master frame prior to the refugee crisis. They also demonstrate the emergence of a new master frame, the "Perils of Asylum." This master frame arises during and due to the "refugee crisis" and incorporates elements of the previous Islamization master frame. The crisis is an opportunity structure through which PEGIDA's message can be modified and updated - but this requires that the old and the new master frame can be aligned with each other. Through that prism, the authors enable us to get to a better understanding of the "crisis" as an opportunity structure for right-wing populist social movements to deepen their roots in German society and broaden their audience.

The different papers in this Thematic Section offer, thus, perspectives on micro and macro discursive and communication strategies regarding events related to international migration and their political interpretation in communication. We hope the readers of SComS will enjoy reading context and country specific analyses informed by different approaches offered by this collection of papers.

\section{References}

Balabanova, E., \& Trandafoiu, R. (2020). Media, migration and human rights: Discourse and resistance in the context of the ero- sion of liberal norms. Journal of Language and Politics, 19(3), 379-390. https://doi. org/10.1075/jlp.20007.bal

Bevelander, P., \&Wodak, R. (2019a). Europe at the crossroads: An introduction. In P. Bevelander \& R. Wodak (Eds.), Europe at the crossroads: Confronting populist, nationalist and global challenges (pp. 7-22). Lund, Sweden: Nordic Academic Press.

Bevelander, P., \&Wodak, R. (Eds.). (2019b). Europe at the crossroads: Confronting populist, nationalist and global challenges. Lund, Sweden: Nordic Academic Press.

Boukala, S., \& Dimitrakopoulou, D. (2018). Absurdity and the "blame game" within the Schengen area: Analyzing Greek (social) media discourses on the refugee crisis. Journal of Immigrant \& Refugee Studies, 16(1-2), 179-197. https://doi.org/10.1080/ 15562948.2017.1303560

Cap, P. (2018). "Britain is full to bursting point!": Immigration themes in the Brexit discourse of the UK Independence Party. In V. Koller, S. Kopf, \& M. Miglbauer (Eds.), Discourses of Brexit (pp. 69-85). London, UK: Routledge.

Krzyżanowski, M., Triandafyllidou, A., \&Wodak, R. (2018). Mediatization and politicization of the "refugee crisis" in Europe. Journal of Immigrant \& Refugee Studies, 16(1-2), 1-14. https://doi.org/10.1080/15562948.2 017.1353189

Musolff, A. (2015). Dehumanizing metaphors in UK immigrant debates in press and online media. Journal of Language Aggression and Conflict, 3(1), 41-56. https://doi. org/10.1075/jlac.3.1.02mus

Musolff, A. (2017). Language aggression in public debates on immigration. Journal of Language Aggression and Conflict, 5(2), 175-177. https://doi.org/10.1075/ jlac.5.2.01mus

Rheindorf, M., \&Wodak, R. (2018). Borders, fences, and limits - Protecting Austria from refugees: Metadiscursive negotiation of meaning in the current refugee crisis. Journal of Immigrant \& Refugee Studies, 16(1-2), 15-38. https://doi.org/10.1080/15 562948.2017.1302032

Serafis, D., Greco, S., Pollaroli, C., \& JerminiMartinez Soria, C. (2020a). Towards an integrated argumentative approach to multimodal critical discourse analysis: 
Evidence from the portrayal of refugees and immigrants in Greek newspapers. Critical Discourse Studies, 17(5), 545-565. https://doi.org/10.1080/17405904.2019.1 701509

Serafis, D., Greco, S., Pollaroli, C., \& JerminiMartinez Soria, C. (2020b). Multimodal arguments in the mainstream press: Illustrating portrayals of migration. In J. Cook (Ed.), Proceedings of the Ontario Society for the Study of Argumentation Conference, Vol. 12 (pp. 1-16). Ontario, Canada: University of Windsor. Retrieved from https:// scholar.uwindsor.ca/cgi/viewcontent. cgi? article $=2563 \&$ context $=$ ossaarchive
Serafis, D., Raimondo, C., Assimakopoulos, S., Greco S., \& Rocci, A. (2021). Argumentative dynamics in representations of migrants and refugees: Evidence from the Italian press during the 'refugee crisis'. Discourse \& Communication, 15(5), 559-581. https://doi. org/10.1177/17504813211017706

Viola, L., \& Musolff, A. (Eds.). (2019). Migration and media: Discourses about identities in crisis. Amsterdam, The Netherlands: John Benjamins.

Wodak, R. (2015). The politics of fear: What right-wing populist discourses mean. London, UK: Sage. 